\title{
Pengaruh Antara Job Insecurity terhadap Stres Karyawan Pelaku Pariwisata Perhotelan Akibat Dampak Pandemi Covid-19 (Studi pada Karyawan Golden Palace Hotel Lombok)
}

\author{
Isra Dewi Kuntary Ibrahim ${ }^{1 *}$, Raden Bagus Faizal Irany Sidharta², Mohammad \\ Najib Rodhi ${ }^{3}$ \\ $\left.\left.{ }^{1 *}\right), 2,3\right)$ Program Studi Manajemen, Fakultas Ekonomi dan Bisnis, Universitas Bumigora \\ Mataram Jalan Ismail Marzuki No.22 Cakranegara Mataram, 83127 \\ E-mail: israibrahim@universitasbumigora.ac.id ${ }^{\left.l^{*}\right)}$
}

\begin{abstract}
ABSTRAK
Penelitian ini bertujuan untuk mengidentifikasi pengaruh signifikan Antara Job Insecurity Terhadap Stres Karyawan Pelaku Pariwisata Perhotelan Akibat Dampak Pandemi Covid-19 (Studi Pada Karyawan Golden Palace Hotel Lombok). Pengumpulan data menggunakan metode penentuan sampel yaitu sampling aksidental dengan total kuesioner yang terkumpul 85 orang. Metode penentuan sampel adalah Non Probability Sampling yaitu sampling aksidental. Analisis dan pengujian hipotesis menggunakan Partial Least Square (PLS) dengan instrument penelitian menggunakan kuesioner melalui google form secara online. Hasil penelitian menunjukkan bahwa terdapat pengaruh positif dan signifikan job insecurity terhadap stres karyawan pelaku pariwisata perhotelan akibat dampak pandemi Covid-19. Pihak manajemen Golden Palace Hotel Lombok diharapkan dapat memperhatikan hasil dari penelitian ini khususnya berkaitan dengan job insecurity dengan tingkat sedang menurut penilaian responden pada masa pandemi ini, agar karyawan dapat tetap merasa aman dan tidak khawatir atas keberlanjutan karirnya. Diharapkan pula bagi pihak manajemen untuk mengelola stress karyawan agar selalu memberikan kinerja terbaiknya untuk perusahaan.
\end{abstract}

Kata Kunci: Covid-19; Job Insecurity; Pariwisata; Partial Least Square (PLS); Stres.

\begin{abstract}
This study aims to identification a significant effect between Job Insecurity on the Stress of Employees in Hospitality Tourism Actors Due to the Impact of the Covid19 Pandemic (Study of Golden Palace Hotel Lombok Employees). Data collection using the method of determining the sample is Non Probability Sampling that is accidental sampling with a total questionnaire collected 85 people. The method of determining the sample is Non Probability Sampling that is accidental sampling. Analysis and testing of hypotheses using Partial Least Square (PLS) with research instruments using a questionnaire via Google form online. The results showed that there was a positive and significant effect of job insecurity on the stress of hospitality tourism employees due to the impact of the Covid-19 pandemic. The management of Golden Palace Hotel Lombok is expected to be able to pay attention to the results of this study, especially with regard to job insecurity at a moderate level according to respondents' assessments during this pandemic, so that employees can continue to feel safe and not worry about the continuity of their careers. It is also expected that management will manage employee stress so that it always provides the best performance for the company.
\end{abstract}

Keywords: Covid-19; Job Insecurity; Tourism; Partial Least Square (PLS); Stress 


\section{PENDAHULUAN}

Pandemi Covid-19 adalah krisis kesehatan yang menjadi fokus di seluruh dunia. Pada awal bulan Januari 2020, korona atau yang dikenal dengan Covid-19 mulai menjadi topik terhangat. Berdasarkan artikel (Ariyanto, 2020) virus covid-19 telah menelan banyak korban di seluruh dunia dan sampai detik ini belum ada obatnya. Virus ini bermula dari otoritas kesehatan di Kota Wuhan, Provinsi Hubei, Tiongkok mendeklarasikan ada 3 orang warganya yang tewas akibat virus itu. Dalam (Citradi, 2020) Jakarta, CNBC Indonesia pada bulan April 2020 menyatakan sejumlah orang sekitar 1,7 juta orang telah terjangkit virus corona. Saat ini virus ini sudah menyebar ke 185 negara dan beberapa negara mencanangkan kebijakan lockdown dan physical distancing setelah menyadari bahwa virus ini benar-benar berbahaya dan mudah menyebar.

Dalam Artikel Ombudsman RI (Tariyah, 2020) yang terbit bulan April dari World Health Organization (WHO) bahwa Corona Virus Disease (Covid-19) merupakan pandemi global. Senin tanggal 2 Maret 2020, Presiden Joko Widodo dengan Menteri Kesehatan Terawan Agus menyatakan di Indonesia sudah ada pasien dengan positif covid-19, maka Indonesia harus siap menghadapi dan mencegah penyebarannya. Salah satunya dengan mengeluarkan kebijakan bekerja dari rumah atau Work From Home (WFH) bagi Aparatur Sipil Negara (ASN) dan perusahaan swasta, seperti halnya juga banyak negara memutuskan untuk menutup sekolah, perguruan tinggi dan universitas. Provinsi Nusa Tenggara Barat (NTB) merupakan Provinsi yang juga terdampak covid 19. Dalam artikel CNN Indonesia, Bulan Maret 2020 lalu Bapak Zulkieflimansyah bersama ibu Hj. Sitti Rohmi Djalilah selaku Gubernur dan Wagub NTB mengkonfirmasi keberadaan satu warga yang positif covid-19 (Stefanie, 2020). Sampai saat ini warga yang terkonfirmasi positif covid 19 di Provinsi NTB makin bertambah setiap harinya diiringi adanya penambahan jumlah warga yang sembuh dan meninggal dunia akibat virus ini. Akibat penambahan tersebut Pemerintah NTB mengeluarkan himbauan yang sejalan dengan Himbauan Pemerintah Pusat untuk meliburkan sekolah, perguruan tinggi, universitas dan kantor-kantor pemerintahan yang diikuti juga dengan perusahaan swasta. Semua kegiatan yang berkaitan dengan belajar mengajar serta bekerja dialihkan dari rumah dengan sistem DARING (online learning) dan aplikasi platform meeting pendukung lainnya demi tetap berjalannya kegiatan pendidikan dan hidupnya perekonomian.

Semakin lama covid 19 berdampaknya pada dunia ekonomi yang mulai lesu, itu dirasakan juga oleh pelaku pariwisata. Dalam Bisnis.com yang dikutip oleh (Karisma, 2020) bahwa tak sedikit pelaku bisnis perjalanan dan wisata merasakan tantangan yang berat seiring 
dengan munculnya pandemi ini dan tak sedikit pula yang menutup bisnisnya karena telah banyak merugi. Selain itu, dalam artikel yang ditulis oleh (Amalia Fitri \& Winarto, 2020) terdapat fakta bahwa Perhimpunan Hotel dan Restoran Indonesia (PHRI) meramalkan industri perhotelan dan restoran akan sangat terpukul bahkan hampir collapse dampak dari mayoritas wilayah memberlakukan pembatasan sosial berskala besar (PSBB). Dampak itupun dialami oleh Golden Palace Hotel Lombok (GPHL) yang merupakan salah satu City Hotel dengan kualifikasi Bintang 4 (Empat) di Kota Mataram Nusa Tenggara Barat. Berdasarkan wawancara dengan pihak Human Resources Development (HRD) GPHL solusi sementara yang dilakukan adalah beberapa pelaku bisnis perjalanan dan wisata adalah mengharuskan karyawannya untuk mengambil cuti, pengurangan jam kerja yang berefek pada berkurangnya gaji yang diterima, bahkan terpaksa merumahkan beberapa karyawannya untuk mengikuti kebijakan WFH tersebut. Berdasarkan data terbaru yang didapatkan total karyawan GPHL Bulan Juni 2020 terdapat total 163 karyawan dengan status permanen dan kontrak sebanyak 123 orang sedangkan karyawan dengan status daily worker sejumlah 40 orang (HRD Golden Palace Hotel, 2020).

Berdasarkan data diatas setiap status karyawan terkena dampak dari kebijakan yang ditetapkan oleh hotel. Hal ini lah yang mengakibatkan karyawan merasa stres, yang awalnya bekerja 6 hari sekali dalam seminggu dengan kepadatan operasional pelayanan dan sekarang akibat adanya kebijakan WFH dari manajemen hotel, operasional hotel terpaksa tidak berjalan seperti biasanya. Menurut (Rivai \& Sagala, 2013) stres merupakan kondisi ketegangan sehingga tercipta ketidakseimbangan fisik dan psikis dimana emosi, proses dalam berpikir karyawan menjadi terganggu. Tinggi dan rendahnya stres mempengaruhi seseorang menghadapi lingkungan. Menurut (Robbins \& Judge, 2008) kemungkinan stres muncul akibat tiga kategori yaitu : Pertama, faktor-faktor Lingkungan meliputi ketidakpastian lingkungan; Kedua, faktor-faktor Perusahaan; Ketiga, faktor-faktor Pribadi biasanya berkaitan dengan masalah keluarga, ekonomi pribadi, kepribadian dan karakter seseorang. Berdasarkan teori diatas, terdapat beberapa penelitian pendukung (Susilo, 2013; A. Fitri, 2013 ) menyatakan bahwa terdapat hubungan antara hubungan interpersonal dan peran individu dengan stress kerja pada karyawan Bank sehingga dinyatakan stres karyawan diakibatkan oleh adanya pengaruh dari ketiga faktor diatas.

Kemudian stres kerja dipengaruhi oleh job insecurity atau rasa tidak aman yang dirasakan karyawan. Dalam (Shropshire \& Kadlec, 2012) menyatakan bahwa keresahan kerja didefinisikan sebagai rasa tidak berdaya mengusahakan kesinambungan situasi kerja diposisi terancam. Peristiwa besar seperti merger, perampingan karyawan, penggunaan teknologi baru, 
dan perubahan industri dapat menjadi sumber ancaman yang dirasakan. Keresahan kerja juga dapat terjadi dari ancaman yang lebih bersifat lokal seperti kondisi pekerjaan, peran ambiguitas, konflik peran, dan locus of control (Shropshire \& Kadlec, 2012). Untuk mendukung pendapat ini dari beberapa studi cross-sectional telah ditunjukkan bahwa karyawan yang menganggap bahwa mereka memiliki masa depan yang tidak pasti dalam pekerjaan mereka sering merasa terancam dan cemas, dan mungkin menunjukkan gejala kesusahan seperti depresi dan somatisisasi (Heaney, Israel \& House, 1994).

Namun dalam hasil penelitian (Try Rikardo \& Susanti, 2015) terdapat hasil berlawanan yaitu job insecurity berpengaruh negatif terhadap stres kerja. Sementara menurut penelitian (Ibrahim, 2019) job insecurity yang dirasakan karyawan hotel bintang 4 (empat) di Kota Mataram rendah, karyawan tidak merasa ada ancaman di pekerjaannya yang membuat karyawan tersebut berniat meninggalkan pekerjaannya yang sekarang, karyawan merasa memiliki kepentingan mengenai potensi dari setiap peristiwa, namun dengan adanya fenomena covid-19 yang terjadi sekarang ini dengan diberlakukannya WFH oleh perusahaan merupakan ancaman bagi karyawan atas pekerjaan yang dimilikinya saat ini. Sehingga peneliti tertarik meneliti pengaruh kedua variabel ini terutama hubungannya di masa pandemi covid-19 dengan topik "Pengaruh Antara Job Insecurity Terhadap Stres Karyawan Pelaku Pariwisata Perhotelan Akibat Dampak Pandemi Covid-19 (Studi Pada Karyawan Golden Palace Hotel Lombok)".

\section{METODE PENELITIAN}

Penelitian ini merupakan studi kasus pada karyawan Golden Palace Hotel Lombok, dilakukan mulai pada tahun 2020. Penelitian ini adalah penelitian kausal yang bertujuan untuk mengetahui hubungan sebab akibat antara dua variabel atau lebih. Adapun populasi dalam penelitian merupakan seluruh karyawan GPHL pada setiap status karyawan baik Permanen, Kontrak dan Daily Worker berjumlah 163 orang. Metode penentuan sampel adalah Non Probability Sampling dengan sampling aksidental yaitu teknik penentuan sampel secara kebetulan, siapapun karyawan dari GPHL yang ditemui oleh peneliti dan diperkirakan mempuni sebagai sumber data dapat dijadikan sampel (Sugiyono, 2009). Peneliti langsung mengambil data dari unit sampling yang menjawab kuesioner melalui google form secara online dan tidak bertemu secara langsung dengan responden akibat dari kebijakan "social distancing" dari pemerintah dan WFH yang diberlakukan oleh perusahaan sehingga total kuesioner yang terkumpul sejumlah 85 . 
Jenis data dalam penelitian ini berupa data kualitatif dimana uraian dan penjelasan yang berkaitan dengan penelitian dikonversikan menjadi data kuantitatif berupa angka-angka yang dapat diukur. Sumber data yang digunakan dalam penelitian ini adalah data Primer yaitu data yang didapatkan langsung dari responden. Data primer diperoleh dengan menyebarkan kuesioner secara online kepada karyawan GPHL pada setiap status karyawan baik Permanen, Kontrak, dan Daily Worker dan Data Sekunder yaitu data pendukung yang diperoleh dari tempat penelitian, jurnal, buku-buku literature dan dokumen lainnya yang ada hubungannya dengan masalah penelitian. Teknik pengumpulan data menggunakan wawancara online, teknik dokumentasi dan angket. Alat pengumpulan data dalam penelitian ini adalah teknik wawancara membutuhkan smartphone dan social media, teknik dokumentasi membutuhkan alat tulis dan buku tulis untuk pencatatan hasil wawancara dan pencatatan atas dokumen yang dimiliki obyek penelitian, teknik angket menggunakan kuesioner online sebagai alat pengumpulan data yang dikirimkan kepada responden untuk melihat "Pengaruh Antara Job Insecurity Terhadap Stres Karyawan Pelaku Pariwisata Perhotelan Akibat Dampak Pandemi Covid-19 (Studi Pada Karyawan Golden Palace Hotel Lombok)”.

Setiap variabel diberikan bobot skala lima yaitu sangat setuju, setuju, cukup, tidak setuju dan sangat tidak setuju. Uji reliabilitas merujuk pada rumus alpha cronbach menurut (Arikunto, 2006) :

$$
\mathrm{r}_{11}=\left[\frac{k}{k-1}\right]\left[1-\frac{\sum \sigma_{b}^{2}}{\sigma_{r}{ }^{2}}\right]
$$

Dimana:

$$
\begin{array}{ll}
\mathrm{r}_{11} & : \text { reliabilitas istrumen } \\
\mathrm{k} & : \text { banyak butir pertanyaan } \\
\sum \sigma_{b}^{2} & : \text { jumlah varians butir } \\
\sigma_{r}^{2} & : \text { varians total }
\end{array}
$$

Teknik analisa data dalam penelitian ini adalah metode scoring dengan skala likert yang berjenjang 5 (lima). Pengujian data dengan metode Partial Least Square (PLS) menurut (Hartono \& Abdillah, 2009) adalah pendekatan lain selain Structural Equation Modeling (SEM) berbasis kovarian menjadi berbasis varian. SEM yang berbasis kovarian menguji kausalitas/teori sedangkan PLS lebih bersifat model prediksi. Persyaratan asumsi normalitas data diabaikan dalam PLS dan sampel bisa dalam jumlah kecil. Konfirmasi atas suatu teori 
untuk mencari hubungan tanpa landasan teori yang kuat dapat menggunakan PLS. Penelitian ini memanfaatkan progam SmartPLS versi 2.0 yang dijalankan dengan media komputer.

\section{HASIL DAN PEMBAHASAN}

Teknik analisa data penelitian ini adalah metode scoring dengan skala likert yang berjenjang 5 (lima). Nilai rata-rata dari masing-masing responden, baik untuk instrumen job insecurity dan stres dibuat kelompok kelas interval dengan jumlah kelas $=5$, rumus menghitungnya :

$$
\text { Interval }=\frac{\text { nilai tertinggi }- \text { nilai terendah }}{\text { jumlah kelas }}
$$

Penelitian ini memiliki interval $=0.8$ dengan perhitungan:

$$
\text { Interval }=\frac{5-1}{5}=0,8
$$

Kemudian dibuat skala distribusi kriteria sebagai berikut :

Tabel 1. Distribusi Interval Kelas Variabel Penelitian

\begin{tabular}{ccc}
\hline & \multicolumn{2}{c}{ Kategori / Pernyataan } \\
\cline { 2 - 3 } Interval & Job Insecurity & Stres \\
\hline $4,20-5,00$ & Sangat tinggi & Sangat tinggi \\
$3,39-4,19$ & Tinggi & Tinggi \\
$2,58-3,38$ & Sedang & Sedang \\
$1,77-2,57$ & Rendah & Rendah \\
$\leq 1,76$ & Sangat rendah & Sangat rendah \\
\hline
\end{tabular}

Sumber: data diolah, 2020

Analisis deskriptif didefinisikan menyampaikan deskripsi dan gambaran hasil data statistik tanpa maksud mengeneralisasikan kesimpulan. Analisis statistik deskriptif ditujukan untuk mendeskripsikan tanggapan responden terkait dengan pilihan pernyataan yang ditujukan oleh frekuensi jawaban responden. Untuk memberikan interpretasi persepsi responden terhadap variabel yang diteliti berdasarkan skor skala likert.

\section{Variabel Stres}

Deskripsi jawaban responden variabel stres kerja sebanyak 10 item. Komponen 10 item pernyataan meliputi Faktor Lingkungan dengan 4 (empat) item pernyataan, faktor perusahaan dan faktor pribadi dengan 3 (tiga) item pernyataan. 
Tabel 2. Distibusi Jawaban Responden Terhadap Stres Karyawan

\begin{tabular}{|c|c|c|c|}
\hline No & STRES & Rata-Rata & Kriteria \\
\hline 1. & $\begin{array}{l}\text { Saya merasa lingkungan tempat saya bekerja saat ini tidak } \\
\text { stabil sehingga membuat saya stres. }\end{array}$ & 2,23 & Rendah \\
\hline 2. & $\begin{array}{l}\text { Saya merasa tidak adanya kepastian lingkungan tempat } \\
\text { saya bekerja saat ini }\end{array}$ & 1,97 & Rendah \\
\hline 3. & $\begin{array}{l}\text { Saya merasa tidak ada kepastian politik sehingga membuat } \\
\text { saya stres. }\end{array}$ & 2,43 & Rendah \\
\hline 4. & $\begin{array}{l}\text { Adanya inovasi teknologi sehingga membuat saya harus } \\
\text { beradaptasi sesegera mungkin. }\end{array}$ & 3,60 & Tinggi \\
\hline 5. & $\begin{array}{l}\text { Saya merasa kondisi tempat kerja saya dalam menjalankan } \\
\text { tugas saat ini tidak maksimal. }\end{array}$ & 2.04 & Rendah \\
\hline 6. & $\begin{array}{l}\text { Saya merasa tidak memahami secara jelas pekerjaan yang } \\
\text { saya jalani sekarang. }\end{array}$ & 1,72 & $\begin{array}{l}\text { Sangat } \\
\text { Rendah }\end{array}$ \\
\hline 7. & $\begin{array}{l}\text { Saya merasa tidak adanya dukungan dari kolega/ rekan } \\
\text { kerja dalam menjalankan pekerjaan saat ini. }\end{array}$ & 1,76 & $\begin{array}{l}\text { Sangat } \\
\text { Rendah }\end{array}$ \\
\hline 8. & $\begin{array}{l}\text { Saya selalu memikirkan tanggung jawab keluarga maka } \\
\text { saya sulit konsentrasi pada saat bekerja. }\end{array}$ & 2,25 & Rendah \\
\hline 9. & $\begin{array}{l}\text { Pikiran yang berlebihan mengenai keluarga membuat saya } \\
\text { tidak maksimal dalam menjalankan tugas. }\end{array}$ & 1,83 & Rendah \\
\hline 10 & $\begin{array}{l}\text { Saya selalu merasa pendapatan saya saat ini tidak } \\
\text { mencukupi kebutuhan hidup saya. }\end{array}$ & 2,91 & Sedang \\
\hline & Rata-rata & 2,27 & Rendah \\
\hline
\end{tabular}

Sumber: Data Primer Diolah, 2020

Tabel diatas menunjukkan dari 85 orang responden yaitu karyawan sebagai responden mengenai stres yang dirasakan mereka selama bekerja di GPHL terutama selama masa pandemi covid 19. Dapat dikategorikan bahwa stres yang dirasakan karyawan selama bekerja tergolong rendah dengan nilai rata-rata 2,27. Hal ini mengindikasikan bahwa karyawan pada GPHL memiliki stres kerja yang rendah selama bekerja terutama di masa pandemi covid-19 ini, karyawan menganggap lingkungan tempat bekerja mereka saat ini dalam keadaan stabil saja serta mereka sebagai karyawan merasa kepastian akan karir mereka walaupun dengan adanya covid-19 kondisi dan situasi setiap sector pekerjaan mengalami ketidakstabilan tetapi hal ini tidak dirasakan oleh karyawan GPHL. Hal yang berkaitan dengan ketidakpastian politik dalam lingkungan kerja pun tidak mempengaruhi tingkat stres karyawan selama bekerja, karyawan juga merasa kondisi tempat kerja mereka saat ini sangat mendukung karyawan dalam menjalankan tugas secara maksimal baik dari fasilitas yang memadai maupun kebutuhan lainnya sebagai karyawan selama bekerja. Karyawan pada GPHL juga merasa sangat memahami dengan jelas tugas dan pekerjaan mereka serta selalu ada dukungan dari kolega atau rekan kerja dalam bekerja secara teamwork. Selain itu karyawan juga merasa 
selalu fokus saat bekerja dan tidak mencampurkan urusan keluarga ke pekerjaan sehingga pekerjaan bisa berjalan dengan baik dan lancar.

Tetapi dalam hasil penelitian ini terdapat 1 item yang memiliki kriteria sedang artinya dapat dikatakan bahwa mayoritas karyawan merasa pendapatan mereka saat ini dapat mencukupi kebutuhan hidup walaupun masih dirasa kurang sehingga itu menjadi salah satu penyebab munculnya stres karyawan apalagi di masa pandemi covid 19 ini. Kebijakan perusahaan yang menyarankan karyawannya untuk mengambil cuti, dirumahkan ataupun pengurangan jam kerja yang berdampak pada berkurangnya pemasukan atau pendapatan mereka selama pandemi covid 19 ini sedangkan kebutuhan akan hidup tetap harus terpenuhi. Selain dari segi pendapatan yang makin berkurang akibat dari adanya pandemi covid19 beberapa karyawan yang memungkinkan bekerja dari rumah diharuskan beradaptasi dengan inovasi teknologi demi mendukung kelancaran pekerjaan dan hal inilah yang menjadi penyebab stress paling tinggi bagi karyawan.

\section{Variabel Job Insecurity}

Deskripsi jawaban responden variabel Job Insecurity sebanyak 5 item pernyataan. Berikut ini distribusi nilai kategori jawabannya :

Tabel 3. Distibusi Jawaban Responden Terhadap Job Insecurity Karyawan

\begin{tabular}{llcc}
\hline \multicolumn{1}{c}{ STRES } & Rata-Rata & Kriteria \\
\hline 1. Saya merasa pekerjaan ini sangat penting bagi saya & 3,31 & Sedang \\
$\begin{array}{l}\text { 2. Kesempatan promosi di tempat kerja saya sangat terbuka } \\
\quad \text { luas }\end{array}$ & 2,97 & Sedang \\
3. Ada rasa takut dalam diri saya jika terjadi pemecatan & 2,84 & Sedang \\
4. Saya merasa khawatir terhadap karir masa depan saya & 3,32 & Sedang \\
$\begin{array}{l}\text { 5. Saya merasa ada ketidakamanan dalam keberlanjutan } \\
\text { pekerjaan saya di tempat saat ini }\end{array}$ & 2,83 & Sedang \\
\hline
\end{tabular}

Sumber: Data Primer Diolah, 2020

Respon dari 85 orang karyawan sebagai responden terhadap job insecurity atau rasa tidak aman yang dirasakan mereka selama bekerja di GPHL terutama selama masa pandemi covid 19. Dapat dikategorikan bahwa stres yang dirasakan karyawan selama bekerja tergolong sedang dengan nilai rata-rata 3,05. Dari 5 item terdapat 5 item dengan kriteria sedang. Hal ini mengindikasikan bahwa karyawan pada GPHL memiliki job insecurity yang sedang selama 
bekerja terutama di masa pandemi covid 19 ini. Karyawan merasa pekerjaan ini cukup penting bagi mereka untuk memenuhi kebutuhan hidup, kesempatan promosi di tempat kerja dirasakan cukup terbuka luas sehingga mereka merasa aman saja dalam bekerja. Ada rasa takut dalam diri masing-masing karyawan jika terjadi pemecatan oleh perusahaan akibat dari pemasukan Hotel yang minim di masa pandemi covid 19 ini. Adapun rasa khawatir terhadap karir masa depan bagi mayoritas karyawan akibatnya karyawan pun merasa adanya ketidakamanan dalam keberlanjutan pekerjaan mereka. Mereka menyadari kesempatan promosi di hotel ini terbuka luas bagi karyawannya namun saat masa pandemi covid 19 inilah yang menimbulkan kekhawatiran tentang keberlanjutan karir mereka di masa depan mengingat pandemi ini masih berlangsung hingga sekarang dan tidak bisa diprediksi kapan akan berakhir.

\section{Uji Asumsi Linearitas}

Uji asumsi linearitas untuk mengidentifikasi model yang diperoleh dalam hubungan antar variable penelitian tepat sehingga termasuk dalam model yang baik atau fit. Dasar pengujian menggunakan metode Curve Fit yang dihitung menggunakan software SPSS. Keputusan apakah hubungan antar variabel tersebut linear menggunakan $p=5 \%$. Hasil pengujian linearitas hubungan antar variabel laten disajikan pada tabel berikut:

Tabel 4. Hasil Pengujian Asumsi Linearitas

\begin{tabular}{ccc}
\hline Hubungan Antar Variabel & Signifikansi & Keterangan \\
\hline Job Insecurity $\rightarrow$ Stres & 0,001 & Linear \\
\hline $\begin{array}{l}\text { Sumber: Data Primer diolah, 2020 } \\
\text { Tampak pada tabel bahwa }\end{array}$ & \\
struktural adalah linear berdasarkan tingkat signifikansinya lebih kecil dari 5 persen $(\mathrm{p}<0,05)$. \\
Dengan demikian asumsi linearitas pada model struktural terpenuhi.
\end{tabular}

\section{EVALUASI MEASUREMENT (OUTER MODEL)}

\section{Uji Validitas Konvergen}

Berdasarkan hasil olah data menggunakan PLS, nilai outer loadings dapat dilihat pada tabel 5 . 


\begin{tabular}{lcc}
\hline & JOB INSECURITY & STRES \\
\hline X1 1 & 0.545794 & \\
X1 2 & 0.581786 & \\
X1 3 & 0.825028 & \\
X1 4 & 0.556199 & \\
X1 5 & 0.512496 & \\
X1 6 & 0.532359 & \\
X1 7 & 0.530799 & \\
X1 8 & 0.787970 & \\
X1 9 & 0.473318 & 0.732956 \\
X1 10 & 0.855475 & 0.900105 \\
X2 1 & & 0.896597 \\
X2 2 & & 0.732956 \\
X2 3 & & 0.896597 \\
X2 4
\end{tabular}

Sumber: Data Primer diolah, 2020

Berdasarkan tabel di atas dapat dilihat bahwa semua indikator baik dari variabel Job Insecurity dan stres memiliki nilai outer loadings di atas 0,3 sehingga tidak ada indikator yang perlu didrop (dibuang) dan semua indikator diikutsertakan dalam pengolahan data selanjutnya.

\section{Uji Validitas Diskriminan}

Berdasarkan hasil olah data menggunakan PLS, nilai AVE yang didapatkan dapat dilihat dibawah ini:

Tabel 6. Uji Validitas Diskriminan

Nilai Square Root of Average Variance Extract (AVE) Variabel Laten

\begin{tabular}{cccc}
\hline Variabel & AVE & $\sqrt{ }$ AVE & Keterangan \\
\hline Job Insecurity & 0,403 & 0,635 & Valid \\
Stres & 0,698 & 0,835 & Valid \\
\hline
\end{tabular}

Sumber: Data Primer diolah, 2020

Hasil uji diatas menunjukkan nilai akar AVE lebih besar dari 0,5 sehingga dapat dinyatakan bahwa nilai korelasi antar variabel stres dan job insecurity valid. 


\section{Reliabilitas Komposit}

Variabel dikatakan memiliki reliabilitas yang tinggi jika nilai composite reliability di atas 0,70 . Berikut nilai composite reliability:

Tabel 7. Nilai Composite Reliability

Variabel

Job Insecurity

Stres

\section{Composite Reliability}

0,866

0,919

Sumber: Data Primer diolah, 2020

Nilai reliabilitas komposit pada tabel di atas untuk setiap konstruk menunjukkan bahwa konstruk Job Insecurity dan Stres adalah reliabel.

Hasil diatas baik convergent dan discriminant validity dan composite reliability mengidentifikasikan indicator-indikator sebagai pengukur variabel laten merupakan pengukur yang valid dan reliabel.

\section{Evaluasi Model Struktural (Inner Model)}

Penilaian terhadap model structural atau inner model dilakukan untuk melihat hubungan antar konstruk, nilai signifikansi dan R-Square model penelitian.

Tabel 8. Nilai R-Square konstruk dependen

\begin{tabular}{cc}
\hline Variabel & R-Square \\
\hline Stres & 0,691 \\
\hline Sumber: Data Primer Diolah, 2020 &
\end{tabular}

Sumber: Data Primer Diolah, 2020

Berdasarkan rumus tersebut maka nilai Q-Square pada penelitian ini adalah

$$
\begin{gathered}
\mathrm{Q}^{2}=1-\left(1-\mathrm{R}_{1}^{2}\right)\left(1-\mathrm{R}_{2}^{2}\right) \ldots .\left(1-\mathrm{Rp}^{2}\right) . \\
\mathrm{Q}^{2}=1-(1-0,691)=47,7481 \%
\end{gathered}
$$

Hasilnya 0,477481 atau 47,8 \% untuk Stres sebagai variabel independen yang memberikan pengaruh terhadap Job Insecurity. Artinya masih ada 52,25\% pengaruh variabel lain terhadap stres karyawan di GPHL diluar model yang tidak diteliti.

\section{Pengujian Koefisien Jalur}

Hasil pengujian hubungan antar variabel penelitian dapat dilihat dari nilai koefisien jalur dan titik kritis (t-statistic) yang signifikan pada $\alpha=0,05$. 
Tabel 9. Hubungan Antar Variabel

\begin{tabular}{ccccc}
\hline No & Hubungan Antar Variabel & $\begin{array}{c}\text { Koefisien } \\
\text { Jalur }\end{array}$ & T-statistik & Kesimpulan \\
\hline Job Insecurity $\rightarrow$ Stres & 0,831 & 25,500 & Signifikan \\
\hline
\end{tabular}

Sumber: Data Primer diolah, 2020

Tabel 9. di atas menunjukkan bahwa dari 2 hubungan antar variabel yang diajukan keduanya memiliki pengaruh yang signifikan. Adapun diagram jalur pada hubungan antar variabel tampak pada gambar berikut :

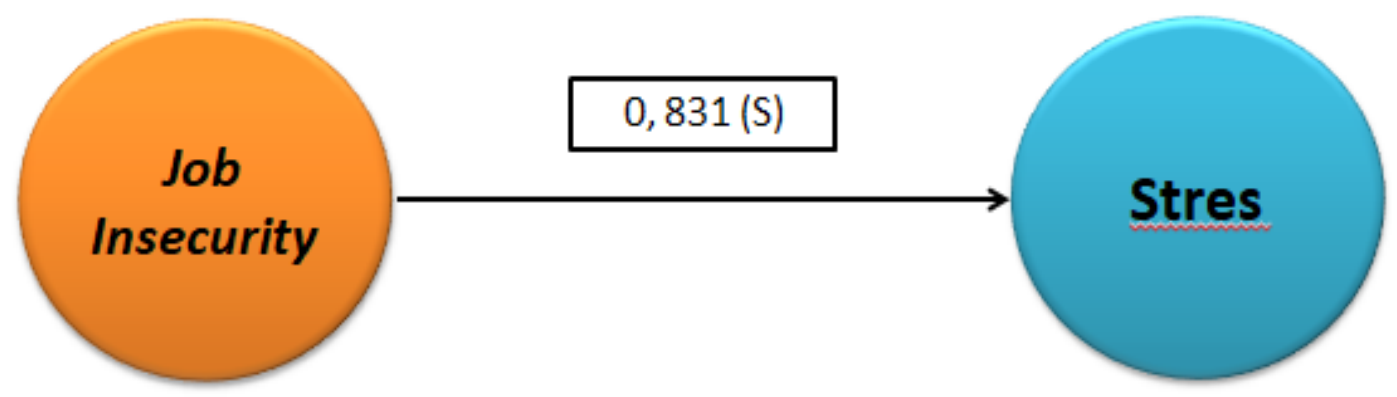

Gambar 1. Diagram Jalur Hasil Pengujian Hipotesis

Sumber: Data Primer Diolah, 2020

Keterangan : $\mathrm{S}=$ Signifikan .

Dari tabel 9 dan gambar 1 di atas menunjukkan bahwa dari 2 hubungan antar variabel yang diajukan semuanya memiliki hubungan antar variabel yang signifikan. Penjelasannya sebagai berikut:

\section{Pengujian Hipotesis 1: Pengaruh Job Insecurity terhadap Stres}

Hipotesis 1 menyatakan Job Insecurity berpengaruh positif signifikan terhadap stres. Hasil uji terhadap koefisien parameter antara Job Insecurity terhadap Stres menunjukkan adanya pengaruh positif dengan nilai koefisien 0,831 dengan nilai t statistic sebesar 25,500 menunjukkan pengaruhnya signifikan. Nilai t statistic tersebut berada diatas nilai kritis 1,680, dengan demikian Ha diterima. Hal ini menunjukkan bahwa job insecurity berpengaruh positif dan signifikan terhadap stres yang dirasakan karyawan. Hal ini berarti jika job insecurity atau adanya rasa tidak aman karyawan pada masa pandemi covid 19 atau korona ini tinggi maka akan tinggi pula stres yang dirasakan oleh karyawan tersebut begitupun sebaliknya jika job insecurity atau adanya rasa tidak aman karyawan pada masa pandemi covid 19 ini rendah maka akan rendah pula stres yang dirasakan oleh karyawan.

Dalam hasil penelitian ini mengindikasikan tanggapan karyawan mengenai job insecurity yang dirasakannya sedang. Waupun karyawan merasa pekerjaan ini cukup penting bagi mereka untuk memenuhi kebutuhan hidup, kesempatan promosi di tempat kerja cukup 
terbuka luas, namun tetap ada rasa takut jika terjadi pemecatan oleh perusahaan akibat dari pemasukan Hotel yang minim di masa pandemi covid 19 ini, ada rasa khawatir terhadap karir masa depan bagi mayoritas karyawan akibatnya karyawan pun merasa adanya ketidakamanan dalam keberlanjutan pekerjaan mereka tetapi rasa tidak aman tersebut tidak membuat stress yang dirasakan karyawan meningkat karena dalam penelitian ini stress karyawan masuk dalam kategori rendah. Mereka menyadari bahwa pekerjaan ini cukup penting bagi mereka, kesempatan promosi di hotel juga terbuka luas bagi karyawannya namun saat masa pandemi covid 19 atau korona inilah yang menimbulkan kekhawatiran tentang keberlanjutan karir mereka di masa depan atau efek terburuknya terjadi pemecatan atau pemutusan hubungan kerja (PHK) mengingat pandemi ini masih berlangsung hingga sekarang dan tidak bisa diprediksi kapan akan berakhir. Namun rasa tidak aman tersebut tidak membuat karyawan merasakan stress berlebihan.

Karyawan merasakan stres akibat dari kebijakan perusahaan yang menyarankan karyawannya untuk mengambil cuti, dirumahkan ataupun pengurangan jam kerja yang berdampak pada berkurangnya pemasukan atau pendapatan mereka selama pandemi covid 19 ini sedangkan kebutuhan akan hidup tetap harus terpenuhi. Namun stres tersebut masih dalam batas wajar dan masih bisa ditolerir oleh karyawan dan tidak berdampak negatif bagi psikologis karyawan dalam bekerja.

\section{KESIMPULAN DAN SARAN}

Berdasarkan hasil analisis dan pembahasan yang telah diuraikan sebelumnya maka dapat disimpulkan bahwa Job Insecurity berpengaruh positif dan signifikan terhadap Stres karyawan Pelaku Pariwisata Perhotelan Akibat Dampak Pandemi Covid-19 studi kasus pada Golden Palace Hotel Lombok. Saran saya sebagai peneliti adalah diharapkan pihak manajemen GPHL dapat memperhatikan hasil dari penelitian ini khususnya berkaitan dengan job insecurity dengan tingkat sedang menurut penilaian responden pada masa pandemi ini, agar karyawan dapat tetap merasa aman dan tidak khawatir atas keberlanjutan karirnya. Diharapkan pula bagi pihak manajemen untuk mengelola stress karyawan agar selalu memberikan kinerja terbaiknya untuk perusahaan. Untuk peneliti berikutnya diharapkan untuk meneliti lebih banyak lagi responden agar mendapatkan hasil yang lebih valid dan mewakili jawaban seluruh karyawan dengan jumlah yang lebih banyak.

Implikasi praktis hasil penelitian ini memberi sumbangan untuk pengambilan keputusan terkait kebijakan selanjutnya yang akan diambil perusahaan demi mengatasi rasa tidak aman yang dimiliki karyawan saat ini akibat pandemi covid-19. Perusahaan perlu memperhatikan 
indikator yang memiliki poin tinggi sehingga dapat menekan stres karyawan atas rasa tidak aman dan khawatir atas keberlanjutan karir mereka dengan mengontrol tingkat ketidakamanan kerja agar mengurangi resiko stres karyawan.

\section{REFERENSI}

Ariyanto. (2020). Asal Mula dan Penyebaran Virus Corona dari Wuhan ke Seluruh Dunia. Retrieved June 25, 2020, from bappeda.ntbprov.go.id website: https://bappeda.ntbprov.go.id/asal-mula-dan-penyebaran-virus-corona-dari-wuhan-keseluruh-dunia/

Citradi, T. (2020). China Berhasil Terapkan Lockdown, Negara Lain Apa Kabar? Retrieved June $1, \quad 2020, \quad$ from cnbcindonesia.com website: cnbcindonesia.com/news/20200411164057-4-151227/china-berhasil-terapkanlockdown-negara-lain-apa-kabar

Fitri, A. (2013). Analisis Faktor-faktor yang Berhubungan dengan Kejadian Stres Kerja pada Karyawan Bank (Studi pada Karyawan Bank Bmt). Jurnal Kesehatan Masyarakat Universitas Diponegoro, 2(1), 18766.

Fitri, Amalia, \& Winarto, Y. (2020). PHRI: Pandemi corona merupakan cobaan besar untuk industri hotel. Retrieved June 20, 2020, from www.kontan.co.id website: https://industri.kontan.co.id/news/phri-pandemi-corona-merupakan-cobaan-besar-untukindustri-hotel

Hartono, J., \& Abdillah, W. (2009). Konsep dan Aplikasi PLS (Partial Least Square) untuk Riset Empiris. Yogyakarta: BPFE.

Heaney, C. A., Israel, B. A., \& House, J. S. (1994). Chronic Job Insecurity among Automobile Workers: Effects on Job Satisfaction and Health. Social Science and Medicine, 38(10), 1431-1437. https://doi.org/10.1016/0277-9536(94)90281-X

HRD Golden Palace Hotel. (2020). Data Update Karyawan. Mataram.

Ibrahim, I. D. K. (2019). Pengaruh Job Insecurity dan Burnout terhadap Turnover Intentions (Studi pada Karyawan Daily Worker dan Outsourcing Hotel Bintang 4 (Empat) di Kota $\begin{array}{llll}\text { Mataram). } \quad \text { Jurnal } & \text { Target, }\end{array}$ https://doi.org/10.1093/acprof:oso/9780199230105.003.0006

Karisma, A. (2020). Dampak Pandemi Corona terhadap Bisnis Perjalanan dan Wisata di Indonesia. (120510180016).

Kurniadi, A., Kamener, D., \& Kamela, I. (2016). Pengaruh Kepribadian Tipe A \& B, Job Insecurity dan Beban Kerja Terhadap Stres Kerja Karyawan Pt. Garda Total Security Padang. Manajemen Universitas Bung Hatta ( 2016 ), 1-12.

Rivai, V., \& Sagala, E. J. (2013). Manajemen Sumber Daya Manusia untuk Perusahaan. In PT Rajagrafindo Persada (Cetakan Ke). Cetakan Kelima, Depok.

Robbins, S. P., \& Judge, T. A. (2008). Perilaku Organisasi Edisi ke-12. Jakarta: Salemba Empat.

Shropshire, J., \& Kadlec, C. (2012). I'm leaving the IT field: The impact of stress, job insecurity, and burnout on IT professionals. International Journal of Information, 2(1), 6-16.

Retrieved from http://esjournals.org/journaloftechnology/archive/vol2no1/vol2no1_2.pdf

Stefanie, C. (2020). NTB Umumkan Kasus Pertama Pasien Positif Corona. Retrieved June 1, 2020, from cnnindonesia.com website: https://www.cnnindonesia.com/nasional/20200324143610-20-486487/ntb-umumkankasus-pertama-pasien-positif-corona

Sugiyono. (2009). Metode Penelitian Kuantitatif, Kualitatif dan R\&D. Bandung: Alfabeta. 
Susilo, T. (2013). Analisis Pengaruh Faktor Lingkungan Fisik dan Non Fisik terhadap Stres Kerja pada PT. Indo Bali di Kecamatan Negara Kabupaten Jimbaran Bali. Journal of Chemical Information and Modeling, 53(9), 1689-1699.

Tariyah. (2020). Kebijakan Bekerja dari Rumah dan Pelayanan Publik. Retrieved June 1, 2020, from ombudsman.go.id website: https://www.ombudsman.go.id/artikel/r/artikel-kebijakan-bekerja-dari-rumah-dan-pelayanan-publik

Try Rikardo, \& Susanti, F. (2015). Pengaruh Jon Insecurity dan Beban Kerja terhadap Stres Kerja pada PT. Garda Total Security Padang. 3(2), 54-67. Retrieved from http://repositorio.unan.edu.ni/2986/1/5624.pdf 